\title{
From the Specter of Polygamy to the Spectacle of Postcoloniality: A Response to Bai on Confucianism, Liberalism, and the Same-Sex Marriage Debate
}

\author{
Yao Lin (iD) \\ New York University Shanghai, Shanghai, China \\ Corresponding author: Yao Lin, email: ahzner@gmail.com
}

(Received 27 August 2021; revised 25 October 2021; accepted 27 October 2021)

In "Confucianism and Same-Sex Marriage," published recently in Politics and Religion, Professor Tongdong Bai argues for a "moderate Confucian position on same-sex marriage," one that supports its legalization and yet endeavors "to use public opinion and social and political policies to encourage heterosexual marriages, and to prevent same-sex marriages from becoming the majority form of marriages" (Bai 2021, 146). Against the backdrop of downright homophobia prevalent among vocal Confucians in mainland China today, Bai claims that his pro-legalization rendition "show[s] a different version of Confucianism that challenges the received perception of Confucianism that it is deeply conservative, a perception that often lies at the core of the rejection of its contemporary relevance, especially by the so-called 'liberals' in China and elsewhere" (Bai 2021, 133). Furthermore, Bai claims that his moderate Confucianism is normatively preferrable to "the typical liberal or individualist position" of a marriage equality supporter, because the specter of polygamy-the conservative trope of invoking polygamy as a reductio ad absurdum against same-sex marriage-imposes "a serious challenge" to liberals but not to moderate Confucians (Bai 2021, 146, 153).

Both of Bai's claims falter upon scrutiny, however. Granted, it is applaudable that Bai tries to dissuade his more conservative Confucian colleagues from opposing the legalization of same-sex marriage. But as section "Whither Confucianism(s)?" of this Response will show, the alternative rendition of Confucianism he presents, along with the way he presents it, is premised on a highly contested conception of what shared Confucian values are; does injustice to Confucians who embrace marriage equality more unreservedly (i.e., without caveats à la Bai); fails to produce new arguments that "enrich the theoretical basis for same-sex marriage" (Bai 2021, 133); and, ironically, reinforces-rather than "challenges"-the "received perception" of Confucianism as deeply conservative. Meanwhile, section "Who's afraid of the specter of polygamy?" will show that Bai's comparison between liberalism and moderate Confucianism relies

(C) The Author(s), 2021. Published by Cambridge University Press on behalf of Religion and Politics Section of the American Political Science Association 
both upon an apparent unfamiliarity with the extensive and nuanced liberal discussions on polygamy, and upon fallacious methods of assessing comparative normative valence.

Finally, section "When postcoloniality becomes spectacle" will offer some concluding thoughts from the perspective of decolonial theory, examining the dynamic of spectacularized postcoloniality that propels the production and consumption of dubious theoretical projects like Bai's. As it turns out, this case serves not only as a cautionary tale of how not to conduct comparative normative theorizing, but also as a cautionary tale of how not to let the spectacle of postcoloniality derail the pursuit of academic decolonization.

\section{Whither Confucianism(s)?}

China decriminalized homosexuality in 1997 and removed it from the official list of mental disorder in 2001. The same year, leading feminist sociologist Li Yinhe (李银河) began to submit annual proposals of same-sex marriage legalization to China's national legislatures (Kam 2015, 92), the news of which registered the topic in the public consciousness and instigated rounds of vigorous debate throughout the next two decades, notwithstanding the government's increasing suppression on feminist and LGBTQ activisms (Longarino 2020; Wang 2021).

Vis-à-vis other intellectual groups in mainland China, Confucians were extreme latecomers to the debate, most of whom only paid attention to the topic because Justice Kennedy of the U.S. Supreme Court had, on June 26, 2015, passingly (and, in their eyes, wrongly) quoted Confucius in his Obergefell opinion approving the right to same-sex marriage. Meanwhile, as Bai has noted, their interventions in the wake of Obergefell were overwhelmingly conservative, ranging from self-styled "Confucian leaders" decrying same-sex marriage as "an unprecedentedly catastrophic challenge to human civilization" (Jiang 2015) and homosexuality as "a deadly tumor resulting from the modern conception of marriage" (Zeng 2015), to reputable Confucian scholars elaborating yin/yang-based cosmological arguments for heteronormativity while also parroting debunked anti-gay pseudoscientific tropes (e.g., about the mental health of children raised by same-sex couples) in academic journals (Zhang 2016).

It goes without saying that not all Confucians in mainland China are conservative; in fact, some have argued for same-sex marriage legalization without attaching Bai-style provisos of dispreference vis-à-vis opposite-sex marriage (e.g., Chen 2018; Xie 2018). In addition, Confucians in Taiwan and Hong Kong are generally much more receptive to marriage equality than their mainland-based counterparts (e.g., Kwong 2016; Deng 2018). Still, given China's outsized visibility vis-à-vis the rest of the sinophone world, and given the outsized proportion of mainland-based Confucians who fervently oppose same-sex marriage, Bai's concern over "the received perception of Confucianism that it is deeply conservative" may not be unfounded.

How to dispel this "received perception"? A simple and obvious way is to highlight counterexamples, i.e., to name the Confucians, both inside and outside mainland China, who have argued for marriage equality, so as to make it evident that the majority of mainland-based Confucians being conservative today does not plausibly indicate any intrinsic disposition of Confucianism per se, but is more likely caused by 
exogenous factors impacting the ideological composition of contemporary mainland Chinese Confucians (e.g., sociopolitical climate, self-selection bias, etc.).

By contrast, Bai's paper hardly gives any indication that such counterexamples exist, let alone the existence of Confucians who have argued for the right to same-sex marriage without caveating-like Bai does-that we should encourage heterosexual marriage vis-à-vis same-sex marriage at sociocultural and policy levels. Indeed, only an endnote mentions three Confucians for having "discussed" same-sex marriage, and its only message is that their discussions either "resonate with" Bai's own, or are "rather preliminary" (Bai 2021, 154 n.8). Thus, by way of nonacknowledgement (especially of the more progressive counterparts), Bai effectively positions his "moderate Confucianism" as the only existing and viable alternative to conservative ones in the relevant sinophone debate.

Noteworthily, such positioning is itself crucial to Bai's substantive argument for his moderate Confucian approach to same-sex marriage, which he claims reflects the "values that are commonly recognized by various schools within the Confucian tradition" and offers "a 'thin' reading of these values that could constitute [a Confucian] 'overlapping consensus"' (Bai 2021, 142). In particular, he identifies "the centrality of family in Confucian moral and political philosophy" as the one thing that all Confucian could and should agree on, and "continuous reproduction" as a "key role of the family" per Confucianism (Bai 2021, 142). Accordingly, same-sex marriage should be legalized but dispreferred: legalized because same-sex couples are perfectly capable of having loving families and raising healthy kids (a point moderate Confucians get, but not conservative Confucians); and dispreferred because they cannot contribute to the continuous reproduction of human society through producing a biological child of both parents (a point Confucians all get, but not "liberals"). Voilà, moderate Confucianism!

Few Confucians would deny that the Confucian tradition takes the institution of family seriously. But this is a far cry from saying they agree that family-qua-value should be central to Confucian normative theorizing (let alone that of "continuous reproduction," which-as anyone versed in the marriage-equality discourse could tell-is anything but "a 'thin' reading" of the value of family). After all, the Confucian tradition also takes various other ideas seriously, such as humaneness (ren 仁), propriety (li 礼), commonwealth (datong 大同), and so on (e.g., Jiang 2018). Would it be surprising if some Confucians insist that the value of family is subsidiary to, and must be appraised in light of, say, the values of humaneness and propriety that they believe are more central to Confucian normative theorizing? And that it is humaneness and propriety, rather than family-qua-value (let alone the loaded "continuous reproduction" reading of it), that should be the exegetic and normative loci of a Confucian "overlapping consensus" (if there is any), and be the default points of departure for contemporary Confucian moral and political theorizing?

Indeed, Confucians have reached far more progressive conclusions on same-sex marriage than Bai's through those other routes. For example, Kwong Chun-Man (广隽文), a young Hongkongese scholar based in Taiwan, made a decidedly Confucian case for marriage equality in the year before Taiwan's Constitutional Court issued its landmark May 24, 2017 ruling that same-sex couples have a 
constitutional right to marry. A follower of the late Lao Sze-Kwang (劳思光, 19272012), who had identified humaneness and propriety-not family and continuous reproduction-as the two quintessential Confucian values, and "grounding propriety in humaneness” (摄礼归仁) as the meta-principle of Confucian political morality, Kwong aptly applied Lao's insight to the debate:

Those who proclaim to "defend traditional Chinese values" cherish a mere formality of marriage: a man and a woman. This contradicts the Confucian view on why propriety is important. Confucius himself believes the essence of propriety lies in the affects it conveys, not in the ritualistic processions and regulations that happen to be practiced at a given point. Genuine propriety does not depend on mere formalities such as whether linen caps or silk caps are worn in a ceremony, or whether or not marriage is between a man and a woman. When new circumstances arise, we always adjust how propriety is practiced, and should always do so on the grounds of humaneness. Insofar as the instantiation of humaneness is unhindered, it is perfectly fine to change the formalities of propriety. (Kwong 2016)

Unsurprisingly, Kwong advocated an unreserved support for marriage equality, without Bai-style strings attached.

To clarify, my point here is not that humaneness and propriety are more central than family-qua-value in Confucian moral and political thought. Rather, it is that (despite all of them taking the family seriously) Confucians disagree on how central the value of family is, and hence on whether family-qua-value is indispensable at all to a Confucian "overlapping consensus," either exegetically or normatively. Moreover, Bai certainly is aware of the disagreement. Just a few years ago, for example, there were heated exchanges between Li Ming-Hui (李明辉), a prominent Taiwan-based Confucian, on the one hand, and dozens of mainland-based Confucians, including $B a i$, on the other hand, over whether the latter have been too fixated on, and too fetishizing of, the idea of family, and whether such fixation and fetishization have contributed to a dangerous trend of cultural nostalgia among mainland-based Confucians (e.g., Bai 2015; Li 2015). As a participant in those exchanges, Bai must have known that the purported Confucian "overlapping consensus" on family-qua-value as the default point of departure for Confucian normative theorizing, which conveniently exempts his moderate Confucianism on same-sex marriage from confronting rival approaches such as Kwong's, is anything but.

Nonetheless, I don't think the conspicuous absence of progressive Confucians in Bai's narrative of the sinophone marriage-equality debate is but a calculated move to deflect substantive contestation from within the Confucian camp. Rather, a more charitable interpretation, I believe, is that Bai is sincerely ambivalent about the extent to which they count, if at all, as Confucians. For instance, in his abovementioned exchange with $\mathrm{Li}$ Ming-Hui, Bai sniffed at $\mathrm{Li}$ and other "Hongkongand-Taiwan neo-Confucians" for "being [liberalism's] cheerleaders [and] embracing democratic political institutions," and mocked them as "castrated Confucians" who "did nothing but capitulate to the West" and hence "deserved political marginalization" (Bai 2015). Granted, Bai does acknowledge and engage with progressive Confucians in his more abstract writings (e.g., Bai 2019); but when it comes to 
concrete policy contentions such as on same-sex marriage, perhaps a Confucianespecially a sinophone Confucian-who reaches the same conclusion as "the typical liberal or individualist position" is simply "capitulating" too much to "Western" intellectual trends, for Bai's taste, to remain recognizably Confucian, and is therefore rightfully excluded from his contours of Confucianism in relation to the same-sex marriage debate.

Relatedly, this exclusion by definitional fiat may also reflect Bai's genuine anxiety over "the rejection of [Confucianism's] contemporary relevance, especially by the so-called 'liberals' in China and elsewhere" (Bai 2021, 133). If conservative Confucians contribute to such rejection by reinforcing "the received perception of Confucianism that it is deeply conservative," then progressive Confucians contribute to such rejection by "surrendering to" and "cheerleading for" liberal agendas such as marriage equality; only Bai, whose family-and-continuous-reproduction-based, neither-conservative-nor-liberal, legalization-plus-dispreference approach "enrich [es] the theoretical basis for same-sex marriage" (Bai 2021, 133), can help Confucianism earn liberals' respect and assert its contemporary relevance.

What Bai does not realize is that his approach supplies nothing new to the debate. Quite the contrary, it is exactly the same approach long held by some conservatives in the West who favor legalizing(-while-dispreferring) same-sex marriage on the basis of "family values," some of whom had, in Obergefell, filed amicus briefs along that line of reasoning, which was largely adopted by Justice Kennedy in his majority opinion (Rauch 2015; Rubin 2015). Misquoting Confucius or not, Kennedy preceded Bai in making the "moderate Confucian" (or, for that matter, "moderate family-values Western conservative") argument. Bai, nonetheless, presents this tired argument as if it were built on an "overlapping consensus" over shared Confucian values, and as if it were the only alternative to conservative Confucianism-both presentations are possible only through his erasure of the more progressive Confucians from the narrative. The irony is, in making the more progressive renditions of Confucianism invisible (and, by definitional fiat, impossible), he unwittingly reinforces "the received perception of Confucianism that it is deeply conservative," which he purports to challenge.

\section{Who's afraid of the specter of polygamy?}

If Bai's positioning within the Confucian camp is questionable, his comparison between liberalism and moderate Confucianism in face of the specter of polygamy (i.e., the scare tactic of invoking polygamy as a reductio against same-sex marriage) is even more problematic. Indeed, its entire process of argumentation (Bai 2021, 14853 ) betrays both a glaring obliviousness to the relevant literature, and an utter lack of methodological awareness on how to properly compare normative theories.

A nomenclatural point is in order before I proceed. Whereas labeling is always a tricky business, the question of who count as "liberals" is arguably far more intractable than that of who count as "Confucians," both because liberalism lacks a foundational figure à la Confucius, and because the term "liberalism" has evolved to have vastly different references and connotations across societies or academic communities. For the purpose of this Response, I simply follow Bai's implicit categorization 
of "liberals" as those who embrace both "the principle of liberty" and "the principle of equality" at the same time (Bai 2021, 149). Naturally, this working definition is broader than some conventional usages of the term while narrower than others; for example, it should include quite a few scholars from more radical intellectual traditions used to using "liberalism" as a pejorative term, and should exclude quite a few self-styled ziyoupai (自由派, literally "liberals") in China who have undergone a "Trumpian metamorphosis" lately (Lin 2021).

It is safe to assume nowadays all thusly-defined liberals support marriage equality unreservedly (i.e., without Bai-style dispreference), though some of the more radical among them may also embrace an eventual abolition of the very institution of marriage (Liu 2015; Banye 2016). By contrast, liberal attitudes toward polygamy remain varied. Two things are worth clarifying here, though. First, as John Corvino has emphasized in his seminal paper rebutting the reductio argument against homosexuality, the question of whether polygamy (or any other type of sexual practice invoked as a reductio) should be accepted is easily separable from that of whether the polygamy-based (or any other) reductio argument can be neutralized; for since "[polygamy] and homosexuality are no more essentially connected than [polygamy] and heterosexuality" (Corvino 2005, 526), liberal defenders of same-sex marriage who disapprove of polygamy can always turn the reductio argument on its head against the opponents of same-sex marriage, and ask rhetorically: if heterosexual marriage is allowed, why not polygamy? In any case, the variety of liberal attitudes toward polygamy lends no credence to the trope of invoking polygamy as a reductio against samesex marriage.

Second, insofar as we are interested not merely in neutralizing the polygamy-based reductio argument against same-sex marriage, but also in appraising the liberal attitudes toward polygamy itself, we must locate the exact level(s) at which the variety of liberal attitudes arises. To begin with, contemporary liberal academic writings on the subject have typically acknowledged the following complexities: that there is nothing inherently objectionable about polygamy per se according to the liberal principles of liberty and equality, for "[genuinely consensual and] egalitarian polygamous relationships, though rare, do occur" (Corvino 2005, 528); that, in practice, polygamous relationships do frequently raise "legitimate concerns about the safety, welfare, and autonomy of the women who are involved"-but so do many other practices ("such as arranged marriages or even the very fact of marriage within a conservative, patriarchal community") that are, and arguably should be, tolerated by liberal states (March 2011, 260); and that, sometimes, "the focus on the patriarchal practices of minority cultures [such as as-practiced polygamy] can have the effect of diverting attention from gender hierarchies within the [monogamous] majority culture" (Song 2005, 476).

Consequently, liberal scholars nowadays seldom insist on a total and permanent ban on polygamy, nor on polygyny specifically. They do diverge, however, on the question of what sort of accompanying regulatory scheme, if and when polygamy is legalized, would strike the best balance between competing legitimate concerns, given the far-from-ideal realities of our world. On the one hand, some argue for undifferentiated, minimal state intervention, such that both polygamy and other forms of marriage (or civil union) are regulated by the same set of baseline civil 
and criminal laws (e.g., the law against marital rape), and no more (e.g., Calhoun 2005; Brake 2010; March 2011; He 2014).

Other liberals, on the other hand, believe that advocates of the minimalist approach either underestimate the extent to which "the entrenched patriarchal structure, and resultant gender power differential, within human societies" could "significantly exacerbate" the gender-inegalitarian effects of minimally regulated polygamy (Lin 2017, 430), or neglect the fact that "marital multiplicity" per se-the defining feature of polygamy - "both increases the costs of intimate negotiation and complicates it in several ways, including raising questions about how power is bargained for and distributed in marriage" (Davis 2010, 1963-1964). Examples of alternative proposals are: using commercial partnership law as a blueprint to establish a set of "default rules" for "plural marital associations" (Davis 2010, 2004); creating a special regulatory procedure for "religious-based polygamy," especially regarding its "entrance and exit" by women (Faucon 2014, 37); licensing a polygamous relationship only when it "completely aggregates" all parings between any two members of the group, and treats all those "meta-marital" relations equally in terms of entitlements and obligations (Lin 2017, 431-32); and so on.

Within this extensive body of nuanced discussions, Bai apparently has only read one article by Andrew March and another by Ronald Den Otter, the only two liberal works on polygamy that are mentioned in the main text of his paper (Bai 2021, 149-150) (compare: he passingly mentions Davis's (2010) article in a one-sentence endnote as if it were merely a scholar's cultural commentary on a Mormonpolygamists-themed TV show (Bai 2021, 156 n.31); one cannot help but wonder whether he has actually read her article). And he does not attempt to take March and Den Otter seriously either; instead, after paraphrasing their liberal defenses of polygamy, Bai immediately pivots to declaring, impressionistically, that "[n]onetheless, ... many [liberals], both in the West and in China, do not feel comfortable with accepting polygamy" (Bai 2021, 150). For someone purportedly comparing liberalism with his own theory, the disinterest in what liberals have actually said is striking.

Had Bai engaged with the literature, he would have known that liberal defenders of same-sex marriage can neutralize the reductio argument regardless of their views on polygamy, as well as that serious liberal writings on polygamy nowadays disagree not on its inherent acceptability but on the best practice for its regulation. Apart falls his unsubstantiated insinuation that liberalism has difficulty confronting the specter of polygamy, then. But what about his comparative claim that moderate Confucianism is better at it than liberalism? Given the limited space of this Response, I will skip over the numerous other leaps and confusions permeating his related discussion, leave them for interested readers to hunt, and only give one example to illustrate the methodological deficits of his comparative normative theorizing.

Following his aforementioned impressionistic declaration that many liberals "do not feel comfortable with accepting polygamy," Bai declares, again impressionistically, that "a hidden reason for [these] liberals to feel uncomfortable with polygamy is their embrace of some radical form of equality, [which] is not cherished by Confucians" (Bai 2021, 151). But even if, arguendo, this is true and even if, arguendo, this "radical form of equality" and its resultant "uncomfortable[ness] with polygamy" are 
objectively bad, so what? After all, hasn't Bai himself admitted that the "radical form of equality" is but one interpretation of the liberal "principle of equality," and that he knows (with March and Den Otter being examples) there are liberals who do not "feel uncomfortable with polygamy"?

Regardless, Bai contends that (moderate) Confucianism per se is normatively preferrable to liberalism per se, by way of showing that adherents of the (presumably) "best" rendition of Confucianism can be more "comfortable with polygamy" than adherents of the (presumably) "worst" rendition of liberalism. Yet, shouldn't we at least compare the "best" with the "best"? Let alone the fact that he maneuvers to grant additional favorable assumptions to one side (e.g., "as long as polygamy remains a minor form of marriage in a large and open society, it may not pose a serious problem to Confucians"), but not to the other (Bai 2021, 153). In effect, he commits what we Chinese may dub the fallacy of Tian Ji's horse-racing (田忌赛马谬误) in assessing comparative normative valence: the best horse in my horde runs faster than one of the lesser horses in your horde, therefore my horde is better than yours; or, the most charitable interpretation of my position is more attractive than an uncharitable interpretation of your position, therefore my position is normatively preferrable to yours.

\section{When postcoloniality becomes spectacle}

Now that the previous two sections have scrutinized Bai's two respective claims closely, this section will take a step back and reflect on the bigger picture his problematic project reveals. Specifically, I submit that the instance is symptomatic of what we may call the dynamic of spectacularized postcoloniality affecting comparative normative theory, a dynamic through which the worthy pursuit of intellectual decolonization sometimes goes awry, celebrating mere spectacles of postcoloniality at the expense of a genuinely decolonized global academia.

As contemporary critical theorists have reiterated, the logic of colonialism still permeates social sciences and humanities today: "[i]f in the colonial past, academic imperialism was maintained via colonial power, today academic neo-colonialism is maintained via the condition of academic dependency" (Alatas 2003, 602). Also, it has been argued that the "most important" among the many dimensions of academic dependency is "dependence on ideas": in the current "global knowledge division of labour," the Western academia is presumed to be the primary (if not the only) producer of "metatheoretical or theoretical" analyses, whereas non-Western thoughts are too often dismissed as either unoriginal or unsophisticated, and non-Western scholars too often relegated to auxiliary roles of replicating Western theories in, and applying them to, the local conditions of respective non-Western societies (Alatas 2003, $604,607)$. In order to break away from academic colonialism, we must strive for a diversification of theoretical perspectives and an accentuation of non-Western theoretical resources. Seen from this angle, the efforts by contemporary Confuciansincluding Bai-to reclaim Confucianism's relevance for normative theorizing are timely and commendable.

In the meantime, Bai's example reminds us how easily a purported reclamation of non-Western theoretical relevance can turn sour. To recap, Bai's "moderate 
Confucian" approach to same-sex marriage is indeed both unoriginal and unsophisticated. It is unoriginal because underneath all its Confucian quotes lies nothing but the tired "family-values-based" moderate-conservative argument for legalizing-whiledispreferring same-sex marriage. And its unsophistication is evident both in how it simply presumes an "overlapping consensus" over "shared Confucian values" despite well-known disagreements by other Confucians, and in how its purported comparison with liberalism betrays both an ignorance of the literature and a propensity for logical and methodological fallacies. (To be clear, this by no means legitimates the colonialist stereotyping of non-Western thoughts as unoriginal or unsophisticated vis-à-vis Western thoughts. After all, the Western academia produces numerous unoriginal and unsophisticated publications too, and no one holds that as a proof of Western thoughts being unoriginal or unsophisticated.)

Yet the biggest problem with Bai's paper is neither unoriginality nor unsophistication. Rather, it is that it actively emulates the academic-colonial tactics of erasure and, as a result, effectively perpetrates the academic-colonial myths about non-Western thoughts.

I have, in section "Whither Confucianism(s)?", detailed how Bai erases progressive Confucians from his contours of contemporary sinophone Confucianism, so as to position his own "moderate Confucianism" as the only viable Confucian alternative to the more conservative and more homophobic variants. In the same vein, Bai's discussion on the reductio argument against same-sex marriage, throughout which only sinophone conservative Confucians and anglophone liberals are cited, gives no hint of the fact that the reductio argument has been systemically investigated and roundly rejected not just by liberals in the West (e.g., Corvino 2005), but by Chinese liberals as well (e.g., Lin 2013; Lin 2017). Indeed, thanks to Chinese liberals' efforts, the sinophone debate on same-sex marriage had largely moved on from the reductio argument by the time conservative (and moderate) Confucians joined it in the wake of Obergefell, who then simply pretended the preceding sinophone discussions on the reductio argument had not existed, and kept wheel-reinventingly raising the specter of polygamy as if it were a newly discovered knockdown argument-causing a commentator to bemoan that "so-called Mainland neo-Confucians really don't like to and don't know how to" argue by way of "public reason" like "Chinese leftwing-liberals do" (Chen 2015).

In other words, just as Bai's self-positioning within the Confucian camp obscures the more progressive renditions of Confucianism, his comparison between moderate Confucianism and liberalism is parasitic on a background narrative that, by way of selective omission, diminishes the vigorousness and fruitfulness of the sinophone debate on same-sex marriage, and instead imparts to readers the false impression of a barren intellectual landscape in contemporary China that awaits (moderate) Confucianism to water and fertilize. This is part of what spectacularized postcoloniality is: the purported relevance of one particular non-Western theory (e.g., moderate Confucianism) is promulgated-as a spectacle-at the expense of the perceived relevance of non-Western intellectual exchanges in general (e.g., the sinophone debate on same-sex marriage). In doing so, the academic-colonial ideology of non-Western theoretical irrelevancy is reinforced, rather than undermined.

Another aspect of spectacularized postcoloniality is exemplified by Bai's snubbing of the "liberal democracy-cheering" Confucians as "castrated Confucians" (Bai 2015), 
as well as by his circumvention of the fact that Chinese liberals had, in the sinophone debate, long preempted the post-Obergefell "Confucian" summoning of the specter of polygamy. In a rush to decolonize intellectually, it is tempting to rigidify the boundaries between what count as "Western" and what count as "non-Western," and write the non-Western thoughts that defy such boundary-policing (e.g., Chinese liberalism, "liberal democracy-cheering" Confucianism, etc.) off as both imitative (i.e., not "truly Western") and inauthentic (i.e., not "non-Western enough"), and therefore historiographically irrelevant to, or existentially illegitimate in, the presentation of a non-Western theoretical landscape. By narrowing the scope of what count as "non-Western" thoughts, purging "quintessentially Western" theoretical perspectives — such as liberalism - from it, and spectacularizing the remaining "authentic" versions purified of alleged intellectual-colonial influences, however, the colonial logic-in this instance, of essentialization, otherization, and museumization of the "non-Western"is once again reinforced, rather than undermined.

How does spectacularized postcoloniality come about? At least two major causes can be discerned in Bai's case, one sociopsychological and the other structural. Sociopsychologically, the project of intellectual decolonization in the non-Western world is often intertwined with various nationalist or identitarian projects of vindication, which, to be sure, are not necessarily bad things, but which nonetheless are fine lines to walk. Indeed, while certainly not all vindicationists in contemporary China embrace the "China model" as offered by the present government, they more or less aspire to "demonstrating the ingenuity-and intrinsic supremacy-of Chinese civilization to the rest of the world with an ['authentically Chinese' normative-theoretical vision] that is both distinctive from and superior to whatever the West has had to offer" (Lin 2021, 98). Consequently, the urge to discount and dismiss the voices of "(Western-)liberalism-affiliated" Chinese theorists, and to overlook the unoriginality and unsophistication of one's own "authentically Chinese" normative theory, is understandably hard to repress.

It is worth reiterating that sociopsychological impacts of this kind are not all-or-nothing but are matters of degree, and that it would be unfair to simply label Bai an "anti-liberal" or "anti-Western" intellectual. Whereas "most contemporary Confucians in mainland China are enthusiastic about President Xi's dream of 'the great rejuvenation of the Chinese nation' [and] are eager to... resume its affiliation and cooperation with the ruling power" despite the latter's acceleratingly totalitarian turn (Jiang 2018, 166), Bai is certainly not one of them. Quite the contrary, it has been remarked that despite his reservations on democracy, "Bai wholeheartedly embraces the liberal components of liberal democracy such as rule of law and rights" (Kim 2021, 281). As a result, even though Bai chides Hongkong-and-Taiwan-based Confucians for being "castrated" by Western liberalism, he himself is frequently called a "liberal Confucian" (ziyoupai rujia) in mainland China, and accused by his conservative peers of "doubtlessly following the liberal school of thought" and "using the hegemonic Western theory to misinterpret and distort Confucianism" (Jiang 2016) - a testament both to the aforementioned referential amorphousness of the term "liberal," and to the complicated and contested nature of distinguishing, and disentangling, genuine decolonial pursuits from vindicationist ones. 
Equally if not more important is the structural cause of spectacularized postcoloniality. For academic colonialism is manifested and sustained not only through "dependence on ideas" but also through "dependence on the media of ideas such as books, scientific journals, proceedings on conferences, working papers and electronic publications of various kinds" (Alatas 2003, 604). In particular, the status quo of anglophone hegemony in global academic publishing constitutes an insurmountable barrier to most sinophone scholars, and puts the few of them who can overcome such barrier under subsequent decontextualizing and alienating "Western gazes." Indeed, even when Bai purports to dissuade his more conservative Confucian colleagues from opposing the legalization of same-sex marriage (Bai 2021, 141-47), he has to write it in English and publish it in a Western journal-a language and a venue that most of his purported Confucian interlocuters likely do not read-in order to "challenge" the "received perception of Confucianism that it is deeply conservative." In other words, the dissuasion has to become purely performative, and detached from the actual sinophone debate, before it can be seen and appraised-as a singled-out spectacle-through the Western eyes.

At the same time, the linguistic barrier also impairs the capacity of the hegemonic anglophone academic community to screen out callous misrepresentations of nonanglophone intellectual landscapes. Such impairment, moreover, is independent of whether or not peer-review per se (or many other conventional academic practices) is of merit (e.g., Heesen and Bright 2021; Rowbottom 2021). On the contrary, it is a fundamentally structural burden that cannot be alleviated without a diversification of academic infrastructures and a dismantlement of anglophone hegemony in global academic publishing, in addition to the aforementioned diversification of theoretical perspectives and accentuation of non-Western theoretical resources. Only then are we able to celebrate the success of academic decolonization, rather than the spectacle of postcoloniality.

Acknowledgment. I would like to thank Professor Nicholas Tampio and the anonymous reviewer for their thoughtful and constructive comments.

\section{References}

Alatas SF (2003) Academic Dependency and the Global Division of Labour in the Social Sciences. Current Sociology 51, 599-613.

Bai T 白䑣东 (2015) Bai's Response to Li (2015), Collected in “Mainland Confucians Respond to Criticism: Hongkong-and-Taiwan Neo-Confucianism Does Not Fit Mainland's Reality.” 大陆儒家回应批评 : 港 台新儒家未必切近大陆现实, The Paper 澎湃新闻, January 26. https://www.thepaper.cn/ newsDetail_forward_1297875 (Accessed 27 August 2021).

Bai T (2019) Against Political Equality: The Confucian Case. Princeton, NJ: Princeton University Press.

Bai T (2021) Confucianism and Same-Sex Marriage. Politics and Religion 14, 132-158.

Banye 半爷 (2016) One Can Both Fight for Marriage Equality and Transcend Marriage. 既争同婚平权, 也能超越婚姻, Initium 端传媒, May 2. https://theinitium.com/article/20160502-opinion-banye-lgbt/ (Accessed 27 August 2021).

Brake E (2010) Minimal Marriage: What Political Liberalism Implies for Marriage Law. Ethics 120, 302-337.

Calhoun C (2005) Who's Afraid of Polygamous Marriage? Lessons for Same-Sex Marriage Advocacy from the History of Polygamy. San Diego Law Review 42, 1023-1042.

Chen C 陈纯 (2015) Neo-Confucians Versus Leftwing-Liberals in Mainland China. 大陆新儒家与左翼自 由主义, Initium 端传媒, August 13. https:/theinitium.com/article/20150814-mainland-liberalismleft/ (Accessed 27 August 2021). 
Chen Z 陈志伟 (2018) Confucian Ideas and the Possibility of Same-Sex Marriage: Our Attitude Toward Traditions. 儒家观念与现代同性婚姻的可能性 : 兼及我们对待传统的态度, International Journal of Chinese \& Comparative Philosophy of Medicine 中外医学哲学 16, 93-97.

Corvino J (2005) Homosexuality and the PIB Argument. Ethics 115, 501-534.

Davis AD (2010) Regulating Polygamy: Intimacy, Default Rules, and Bargaining for Equality. Columbia Law Review 110, 1955-2046.

Deng X [Tang, Siu Fu] 邓小虎 (2018) Same-Sex Marriage and Confucian Ethics: A Response to Professor Fang Xudong. 同性婚姻与儒家伦理：回应方旭东教授, International Journal of Chinese \& Comparative Philosophy of Medicine 中外医学哲学 16, 119-123.

Faucon CE (2014) Marriage Outlaws: Regulating Polygamy in America. Duke Journal of Gender Law \& Policy 22, 1-54.

He X 何小培 (2014) My Anti-traditional Threesome Wedding in Beijing. 我在北京举行的反传统三人婚 礼, Queer Lala Times 酷拉时报 1, 98-101. https://cnlgbtdata.com/files/uploads/2019/03/ QueerLalaTimes_vol.1_2014.pdf.pdf (Accessed 27 August 2021).

Heesen R and Bright LK (2021) Is Peer Review a Good Idea? British Journal for the Philosophy of Science 72, 635-663.

Jiang Q 蒋庆 (2015) Confucian Leader Jiang Qing on Same-Sex Marriage: an Unprecedentedly Catastrophic Challenge to Human Civilization. 儒家领袖蒋庆论同性婚姻 : 人类文明亘古未有的毁 灭性挑战, The Paper 澎湃新闻, July 22. https://www.thepaper.cn/newsDetail_forward_1355289 (Accessed 27 August 2021).

Jiang Q 蒋庆 (2016) Jiang Qing's Response to Bai Tongdong: Mencius Misunderstood as a Chinese Forerunner of Modern Western Democratic Politics. 蒋庆回应白粀东 : 孟子被误解成现代西方民 主政治的中国先驱，The Paper 澎湃新闻，August 23. https://www.thepaper.cn/newsDetail_ forward_1514140 (Accessed 27 August 2021).

Jiang Y-H (2018) Confucian Political Theory in Contemporary China. Annual Review of Political Science 21, 155-173.

Kam LYL 金晔路 (2015) A Marriage Revolution of Chinese LGBT Rights Movement. 中国同志运动的婚 姻革命, Queer Lala Times 酷拉时报 2, 92-93. https://cnlgbtdata.com/files/uploads/2019/03/ QueerLalaTimes_vol.2_2015.pdf.pdf (27 Accessed August 2021).

Kim S (2021) Liberalism Without Democracy? The Review of Politics 83, 278-281.

Kwong C-M 广隽文 (2016) Will Gay Marriage Destroy 'Chinese Culture’? 同志婚姻会令「中华文化」 毁于一旦吗?, Opinions at Commonwealth Magazine 独立评论@天下, December 27. https://opinion. cw.com.tw/blog/profile/52/article/5164 (Accessed 27 August 2021).

Li M-H 李明辉 (2015) I Disapprove Mainland Neo-confucianism. 我不认同「大陆新儒家」, Confucians 儒家网, January 23. https://www.rujiazg.com/article/4754 (Accessed 27 August 2021).

Lin Y 林圭 (2013) The Slippery Slope of Same-Sex Marriage. 同性婚姻的滑坡, Weibo 新浪微博, May 19. Original post deleted by censorship in 2019; screenshot available at https://ww1.sinaimg.cn/mw690/ 68cd22cbgw1e4wvl3pxojj20c87tehdu.jpg (Accessed 27 August 2021).

Lin Y 林圭 (2017) Same-Sex Marriage, Sexual Minority Rights and the 'Moral Slippery Slope' Argument. 同性婚姻、性少数权益与「道德滑坡」论, Tsinghua Studies of Western Philosophy 清华西方哲学研 究 3, 411-437. https://papers.ssrn.com/sol3/papers.cfm?abstract_id=3452156 (Accessed 27 August 2021).

Lin Y (2021) Beaconism and the Trumpian Metamorphosis of Chinese Liberal Intellectuals. Journal of Contemporary China 30, 85-101.

Liu W 刘文 (2015) The Queer Paranoia of Homonormativity and Reparative Reading of Taiwanese LGBT Movement. 酷儿左翼「赶英超美」?「同性恋正典化」的偏执及台湾同志运动的修复梌释, Applied Ethics Review 应用伦理评论 58, 101-128.

Longarino D (2020) Precarious Progress: Advocacy for the Human Rights of LGBT People in China. New York, NY: OutRight Action International. https:/outrightinternational.org/sites/default/files/ PrecariousProgress_2020_1215.pdf (27 Accessed August 2021).

March AF (2011) Is there a Right to Polygamy? Marriage, Equality and Subsidizing Families in Liberal Public Justification. Journal of Moral Philosophy 8, 246-272.

Rauch J (2015) The Supreme Court Weds Gay Marriage to Family Values. Brookings, June 26. https://www. brookings.edu/blog/fixgov/2015/06/26/the-supreme-court-weds-gay-marriage-to-family-values/ (Accessed 27 August 2021). 
Rowbottom DP (2021) Peer Review May Not be Such a Bad Idea: Response to Heesen and Bright. British Journal for the Philosophy of Science. Online first. https://doi.org/10.1086/714787 (Accessed 27 August 2021).

Rubin J (2015) Conservatives Filing Brief in Favor of Gay Marriage. Washington Post, March 3. https:// www.washingtonpost.com/blogs/right-turn/wp/2015/03/03/conservatives-filing-brief-in-favor-of-gaymarriage/ (Accessed 27 August 2021).

Song S (2005) Majority Norms, Multiculturalism, and Gender Equality. American Political Science Review 99, 473-489.

Wang SY (2021) Unfinished Revolution: An Overview of Three Decades of LGBT Activism in China. Made in China Journal, July 15. https://madeinchinajournal.com/2021/07/15/unfinished-revolution-an-overview-of-three-decades-of-lgbt-activism-in-china/ (Accessed 27 August 2021).

Xie G 谢广宽 (2018) Is Same-Sex Marriage Compatible with Confucianism? 儒家信仰与同性婚姻 : 二者 能否兼得, International Journal of Chinese \& Comparative Philosophy of Medicine 中外医学哲学 16, 137-140.

Zeng Y 曾亦 (2015) Homosexuality is a Deadly Tumor Resulting from the Modern Conception of Marriage. 同性恋是现代婚姻观结出的毒瘤, Confucians 儒家网, June 27, 2016. https://www.rujiazg. com/article/id/5718/ (Accessed 27 August 2021).

Zhang X 张祥龙 (2016) How Should Confucianism View the Legalization of Same-Sex Marriage? 儒家会 如何看待同性婚姻的合法化, Journal of Renmin University of China 中国人民大学学报 30, 62-70.

Cite this article: Lin Y (2022). From the Specter of Polygamy to the Spectacle of Postcoloniality: A Response to Bai on Confucianism, Liberalism, and the Same-Sex Marriage Debate. Politics and Religion 15, 215-227. https://doi.org/10.1017/S1755048321000304 